\title{
Study of Quality Assurance For Peumus Boldus M Products By Botanic Profiling, Extraction Optimization, HPLC Quantification and Antioxidant Assay
}

\author{
Cristiane Cardoso Correia Teixeira, Tatiana Pereira de Freitas Cabral, João Paulo Barreto de Sousa, Simone de Pádua Teixeira, Jairo \\ Kenupp Bastos, Luis Alexandre Pedro de Freitas*
}

Departamento de Ciências Farmacêuticas, Núcleo de Pesquisas em Produtos Naturais e Sintéticos, Faculdade de Ciências Farmacêuticas de Ribeirão Preto, Universidade de São Paulo, Via do Café, S/N, 14040-903, Ribeirão Preto, SP, BRAZIL.

\begin{abstract}
Introduction: The boldo leaf has several traditional folk medicinal uses, such as for gallbladder, hepatic problems, digestive disorders, rheumatism and others. In the work reported herein, botanic profiling, extraction optimization by Soxhlet, quantification of boldine by an easy/simple to run HPLC method and antioxidant assay are proposed for the quality assurance of boldo dried leaves, standardized extracts, dried extracts, tablets and capsules. Materials and Methods: In this present work we are studying a systematic approach in the quality assurance study of quality assurance for Peumus boldus $\mathrm{M}$ products by the ascertainment of pharmacobotanic parameters for boldo identification, investigation of the extraction parameters by Soxhlet method, development and validation of an easy/simple to run HPLC method to quantify boldine in the raw drug, extracts, commercial tablets, capsules and coated tablets, and antioxidant assay. Results: The plant material was submitted to a pharmacognostic evaluation through morpho-anatomical diagnosis, showing that starlike trichomes can be used for boldo authentication. The HPLC validated analytical method is reliable, accurate and precise for boldine quantification. Furthermore, the Soxhlet extraction conditions were optimized. Conclusion: The methods proposed in this paper can be used for the quality assurance of boldo dried leaves,
\end{abstract}

standardized extracts, dried extracts, tablets and capsules.

Key words: Antioxidant activity, Boldine, Peumus boldus, Pharmacognostic evaluation, Quantitation.

Key messages: No paper was devoted to develop a comprehensive study on the quality assurance boldo-based products. In these work, botanic profiling, extraction optimization, quantification of boldine by an easy/ simple to run HPLC method and antioxidant assay are proposed for the quality assurance of boldo dried leaves, standardized extracts, tablets and capsules.

\section{Correspondence:}

Luis Alexandre Pedro de Freitas,

Via do Café, S/N, 14040-903,

Ribeirão Preto, SP, BRAZIL.

Ph no: +55-16-3315-4430, +55-16-3315-4225

Email: lapdfrei@usp.br

DOI : $10.5530 /$ pj.2016.3.16

\section{INTRODUCTION}

Peumus boldus Molina ("boldo") is a shrub or small tree native from Chile that belongs to family Monimiaceae, which is well adapted to Brazilian soil and climate. Studies on the chemical constituents of boldo, beginning in the second half of last century, continue to appear. Boldo leaves reportedly contain $1.2 \%$ of tannins and $2-3 \%$ of essential oils (up to $45 \%$ ascaridole and $30 \%$ cineole, and at least 22 other identified constituents, mainly terpenoids). ${ }^{1-3}$ One of the major active components of boldo is the alkaloid boldine, which is claimed to be responsible for the actions of boldo, and it has well recognized antioxidant activity. ${ }^{4,5}$ Dried leaves of Peumus boldus have been reported to contain alkaloids in the $0.25-0.54 \%$ or $0.4-0.5 \%$ range, of which approximately $12-19 \%$ are boldine. ${ }^{3}$ Boldo bark is an unusually rich source of alkaloids, of which boldine makes up about $75 \%$. Moreover, recently studies suggested that the flavonoid fraction from boldo is decisive for this plant antioxidant activity. ${ }^{6-8}$

The boldo leaf has several traditional folk medicinal uses, such as for gallbladder, hepatic problems, digestive disorders, rheumatism and others. ${ }^{2,9-12}$ In the scientific literature, boldo gastric action was confirmed by the increased gastric juice excretion, diuretic and uric acid excretion, but many other studies confirm its properties as cytoprotective, antiinflammatory and antipyretic, hepatoprotective, anti-atherosclerotic, antimicrobial, hypoglycemic and anti-oxidative aid in rats with induced diabetes, as well as effect against the pathogenic bacteria Helicobacter pylor. ${ }^{13-18,10,19}$
A renewed interest for herbal medicines and phytotherapy has fostered worldwide research for extracting biologically active compounds from a variety of plant raw materials. ${ }^{20,21}$ In addition, adulteration and misidentification of crude drug still exist and the development of standardization and quality control of herbal medicines are needed to be prioritized at the earliest stage. ${ }^{22}$

Moreover, to develop a phytomedicine, it is important to develop validated analytical method bearing good performance parameters such as: selectivity, linearity, accuracy, precision and recovery over the specified range that an analyte is analyzed. In order to analyze complex samples, such as extract, high performance liquid chromatography (HPLC) is a good tool not only for separating target compounds, but also for revealing the peaks interfering with the analytes. ${ }^{23}$

In the 60 years since the first analytical method for quantifying boldine in boldo was published, ${ }^{24}$ several other methods using various approaches including densitometry, ${ }^{25}$ spectrofluorimetry, ${ }^{26,27}$ micellar electrokinetic chromatography, ${ }^{28,29}$ voltammetry, ${ }^{30,31}$ and LC-NMR have been described. ${ }^{32}$ The high performance liquid chromatography (HPLC) method coupled to a UV detector was developed by Pietta et al. ${ }^{33}$ and this procedure is currently used in different pharmacopoeias for pharmaceutical boldo preparations. Considering the use of boldo and its alkaloids in pharmaceutical manufacturing, the implementation of analytical methods is required to enable the highly sensitive and selectivity detection of boldine in these preparations. It is noteworthy that there are some works in the 
literature describing analytical method for boldo and its products, but none has developed a thoroughtful approach for quality assurance of boldo products.

The aim of the present work was to study a systematic approach in the quality assurance study of quality assurance for Peumus boldus $\mathrm{M}$ products by the ascertainment of pharmacobotanic parameters for boldo identification, investigation of the extraction parameters by Soxhlet method, development and validation of an easy/simple to run HPLC method to quantify boldine in the raw drug, extracts, commercial tablets, capsules and coated tablets, and antioxidant assay. It can be used for routine quality control of boldo materials. Furthermore, the Soxhlet extraction conditions were optimized.

\section{MATERIALS AND METHODS}

\section{Plant material}

The dry ground leaves of Peumus boldus were supplied by Quimer Ltda (São Paulo, Brazil), and processed in a cutting mill for size reduction. The powder was submitted to microscopic particle size analysis using the software Image J (NIH, USA) and total and acid insoluble ash, moisture content and swelling ratio, following the methods found in the pharmacopoeia. ${ }^{34}$

\section{Plant authenticity}

The plant authenticity was confirmed by using dried and milled leaves. The milled leaves were sieved in three size ranges with mean diameters of $75 \mu \mathrm{m}, 180 \mu \mathrm{m}$ and $355 \mu \mathrm{m}$. Then, it was hydrated in warm water until complete immersion and processed for macro and microscopic observations under light (LM) and scanning electron microscopy (SEM).

The leaf surface was analyzed under SEM. For that, regions of central vein and margin, in both abaxial and adaxial surfaces of the leaf, and also the milled leaf were dehydrated in an alcohol series, critical point dried in a Bal-Tec CPD 030 apparatus, coated with a thin gold layer in a Bal-Tec SCD 050 and observed in a SEM microscope (Jeol JSM 5200) connected to a photographic set (Sinar 67).

The leaf anatomy was analyzed under LM. For that, portions of central vein and margin were transversally hand cut, stained with five different dyes, as shown in Table 1, observed and illustrated in a light microscope (Leica DM) connected to a digital camera (Leica DFC 320). Whole leaves were also analyzed under LM after clearing and staining according to Berlyn and Miksche (1976). Illustrations obtained were then compared with data previously reported for Peumus boldus. ${ }^{35,36}$

\section{Chemicals and Reagents}

Anhydrous disodium hydrogen phosphate was acquired from Carlo Erba Reagents (Brazil), and deionized water was purified by Milli-Q-plus filter systems (Millipore, Bedford, MA, USA). Analytical grade acetonitrile and triethylamine were purchased from Synth (Brazil).

\section{Sample preparation of pharmaceutical formulations}

Capsule, dragee and tablet $(15 \mathrm{mg})$ were powdered and extracted with $6 \mathrm{~mL}$ of a solution $\mathrm{HCl} 0.05 \mathrm{~N}(\mathrm{pH}=3)$ and $6 \mathrm{~mL}$ of chloroform in an extraction funnel. The aqueous phase was collected and the washing procedure was repeated twice. Approximately $2 \mathrm{~mL}$ of $\mathrm{NaOH} 0.3 \mathrm{~N}$ was added to the aqueous phase until $\mathrm{pH}=12$, and then it was partitioned three times with chloroform $(8 \mathrm{~mL})$. The fluid extracts were filtered in $0.45 \mathrm{~mm}$ (Millipore ${ }^{\oplus}$ ) membrane and dried under air stream at room temperature. The dry matter was diluted in the acetonitrile/water/diethylamine (1:1:0.2 v/v/v) and analyzed by HPLC.

\section{Soxhlet extraction and extracts preparation}

For that, $40 \mathrm{~g}$ of powdered boldo leaf was extracted in a Soxhlet apparatus using $500 \mathrm{~mL}$ of solvent (ethanol $70 \%$, ethanol $96 \%$ or acetic acid $1 \mathrm{M}$ solutions). The effects of type of solvent and extraction time on boldine and flavonoid yieldings, as well as on antioxidant activity by the DPPH method were investigated (Table 2). The experiments were undertaken in triplicate and the statistical analysis was carried out by paired t-test.

After that, the extract was partitioned with $6 \mathrm{~mL}$ of a solution $\mathrm{HCl} 0.05$ $\mathrm{N}(\mathrm{pH}=3)$ and $6 \mathrm{~mL}$ of chloroform in an extraction funnel. The aqueous phase was collected and the washing procedure was repeated twice. Approximately $2 \mathrm{~mL}$ of $\mathrm{NaOH} 0.3 \mathrm{~N}$ was added to the aqueous phase until $\mathrm{pH}=12$, and then it was partitioned three times with chloroform $(8 \mathrm{~mL})$. The fluid extracts were filtered in $0.45 \mathrm{~mm}$ (Millipore $\left.{ }^{\circledR}\right) \mathrm{mem}$ brane and dried under air stream at room temperature. The dry matter was diluted in the acetonitrile/water/diethylamine (1:1:0.2 v/v/v) and injected in the HPLC.

\section{Total flavonoid analysis}

The flavonoid contents of boldo extracts were determined in triplicate. For that, $0.5 \mathrm{~mL}$ of the extract was added to $0.5 \mathrm{~mL}$ of ethanol solution containing $2 \%$ of $\mathrm{AlCl}_{3}$. The solution was read at absorbance of $420 \mathrm{~nm}$ after 60 min. A calibration curve was prepared with 1, 5, 10, 20 and $25 \mathrm{mg} / \mathrm{mL}^{-1}$ of quercetin (Sigma Aldrich, USA) submitted to the same procedure described above. The quercetin curve was used as reference to calculate the total flavonoid content. ${ }^{37}$

\section{Antioxidant activity by $D P P H(A A)$}

The antioxidant activity was determined using the stable radical 2, 2-diphenylpicrylhydrazil (DPPH, Sigma-Aldrich, USA). ${ }^{37}$ Aqueous solutions of dry extracts were prepared in five concentrations and $100 \mathrm{~mL}$ aliquots were diluted with $1 \mathrm{~mL}$ acetate buffer ( $\mathrm{pH}$ 5.5) added with 500 $\mathrm{mL} \mathrm{DPPH}(250 \mathrm{mM})$ and allowed to stand for $10 \mathrm{~min}$ at room temperature. The absorbency was read in a spectrophotometer M330 (Camspec, $\mathrm{UK})$ at $510 \mathrm{~nm}$. Negative control was prepared with $1.6 \mathrm{~mL}$ ethanol, $1 \mathrm{~mL}$ acetate buffer, while positive control, $\mathrm{C}^{+}$, was prepared with $1.1 \mathrm{~mL}$ ethanol, $1 \mathrm{~mL}$ acetate buffer and $0.5 \mathrm{~mL}$ DPPH $250 \mathrm{mM}$. The percent antioxidant inhibition was estimated by Equation:

$$
\% \text { inhibition }=100-\frac{(A * 100)}{C+}
$$

The results were expressed as $\mathrm{IC}_{50}$, e.g. the extract concentration $\left(\mathrm{mg} / \mathrm{mL}^{-1}\right)$ required to inhibit $50 \%$ of the DPPH oxidation.

\section{Analytical HPLC Conditions for Boldine Analysis}

Extracts were analyzed by high performance liquid chromatography (HPLC Shimadzu, model SPD-10a), equipped with a Shimadzu pump model LC-10AT, diode array detector UV-Vis-DAD Shimadzu (model SPD-10A), and a chromatopac (model C-R6A). The column used was a reverse phase $\mathrm{C}-18$, operating in isocratic mode with $0.6 \mathrm{~mL} \mathrm{~min} \mathrm{~m}^{-1}$ of solution of acetonitrile/water/triethylamine (1:1:0.2 v/v/v), pH 4 adjusted with a $10 \%$ solution of phosphoric acid. The total run time was $20 \mathrm{~min}$.

\section{Validation of HPLC method}

Validation was undertaken following the parameters described by the Brazilian Sanitary Vigilance Agency, ${ }^{38}$ Food and Drug Administration (FDA), ${ }^{39}$ Ribani and collaborators ${ }^{40}$ and Tossi and collaborators, ${ }^{41,42}$ including linearity, limits of detection (LOD) and quantitation (LOQ), selectivity, precision (intra-assay and inter-assay), accuracy and recov- 
ery. Thus, the analytical method was validated to quantify boldine samples obtained from plant extracts, and commercialized tablet, capsule and dragee formulations.

\section{Selectivity}

The selectivity and search for interfering peaks were performed by comparing the chromatographic profile of boldine standard with the chromatograms obtained from plant extracts, and commercial formulations (tablet, capsule and dragee). ${ }^{41,42}$

\section{Linearity}

The linearity of the analytical standard boldine was determined by constructing analytical curves, from which the respective correlation coefficients (r) was determined. Solutions were prepared in phase mobile considering a wide range of boldine standard 99.6\% (Sigma-Aldrich Inc) concentrations from 0.4 to $800 \mu \mathrm{g} / \mathrm{mL}^{-1}$, producing 13 data points for the standard compound. The relative responses, i.e. the ratio of boldine concentrations to peak areas were plotted against the concentration and the linear range was selected from points within the $95 \%$ confidence interval. All analyses were performed in triplicate. ${ }^{40}$

\section{Limit of detection and limit of quantitation}

The detection (LOD) and quantification (LOQ) limits were determined by the linear and angular coefficients of the analytical curve prepared with boldine concentrations ranging from 0.4 to $24 \mu \mathrm{g} / \mathrm{mL}$, considering standard deviation of the responses (s) and the slope of the analytical curves (S). Thus, the curves were produced in triplicate and values applied to Equations (Eq.(2) and Eq. (3)). ${ }^{40-42}$

$$
L O D=3.3 \times s / S
$$

$$
L O Q=10 \times s / S
$$

\section{Precision}

The precision parameter was evaluated at two levels of precision, repeatability (intra-assay) and intermediate precision (inter-assays). The intra-assay was undertaken by analyses of six repetitions of analytical standards at concentration $(30 \mu \mathrm{g} / \mathrm{mL})$ on the same day under the same experimental conditions. For the inter-assay evaluation, solutions at the same concentrations were analyzed on six consecutive days. The data obtained were expressed as relative standard deviation (RSD \%). ${ }^{40-42}$

\section{Accuracy and recovery of boldine from plant extract}

Accuracy was evaluated through recovery studies using a method of spiking with the chemical marker the previously exhaustively extracted matrix. For that, $40 \mathrm{~g}$ of drying and powered Peumus boldos leaves were exhaustively extracted with $500 \mathrm{~mL}$ of a aqueous ethanol solution $70 \%$, using a Soxhlet apparatus to reduce the contend of boldine to trace amounts, wich was confirmed by HPLC analysis. After that, the matrix was spiked by the addition the boldine in three levels of concentration: low, medium and high, corresponding to $0.75 \%, 1.5 \%$ and $3 \%(\mathrm{w} / \mathrm{w})$, respectively. Then, the biomass was preceded as described for the fluid extract (item 2.5). The results were expressed as mean recovery percentage (R) according to Equation (Eq. (4)):40-42

$$
R 1=(\text { test area of compound }) /(\text { control area of compound }) \times 100
$$

\section{RESULTS}

\section{Morphological evaluation of boldo leaves}

The whole leaves were simple, coriaceous, concolor, symmetric, elliptic, with obtuse apex, round and symmetrical base, entire and curved margins; adaxial surface was roughness and the abaxial surface was smooth (Figure 1a and b), the petiole was canaliculated.

A thick cuticle covered the leaf epidermis (Figure 2a). The epidermis was two layered in the adaxial side (Figure $2 \mathrm{~b}$ ) and one layered in the abaxial side (Figure 2c). Epidermic cells were thick-walled and pectocelulosic. Stomata and simple stellate trichomes were found on the abaxial surface (Figure 2c).

The adaptive value of leaf trichomes is related to the economy of water by plants, because they allow an increase in the sunlight reflection, reducing the leaf temperature and consequently, the transpiration, or due to the increase in the air thickness through which the water must spread. ${ }^{43,44}$

The mesophyll was dorsiventral, and contained oil secreting cells (content positive to Sudan III, Figure 2e) and crystal sand cells (Figure 2f). The content and walls of epidermic and parenchymatic cells slightly reacted for alkaloids and phenolic compounds (Figure $3 \mathrm{a}$ and $\mathrm{b}$ ).
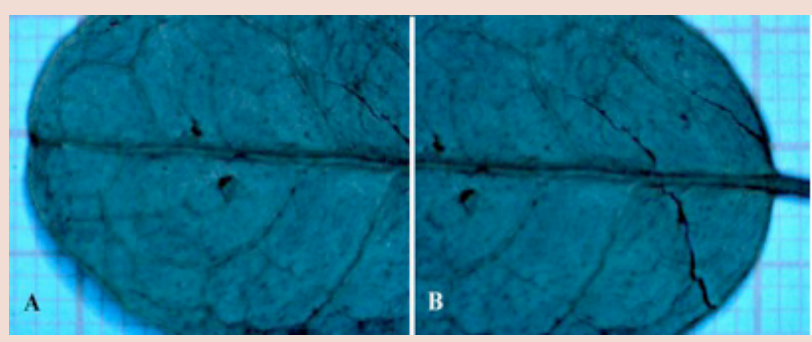

Figure 1: Dried leaf of Peumusboldus (M.)

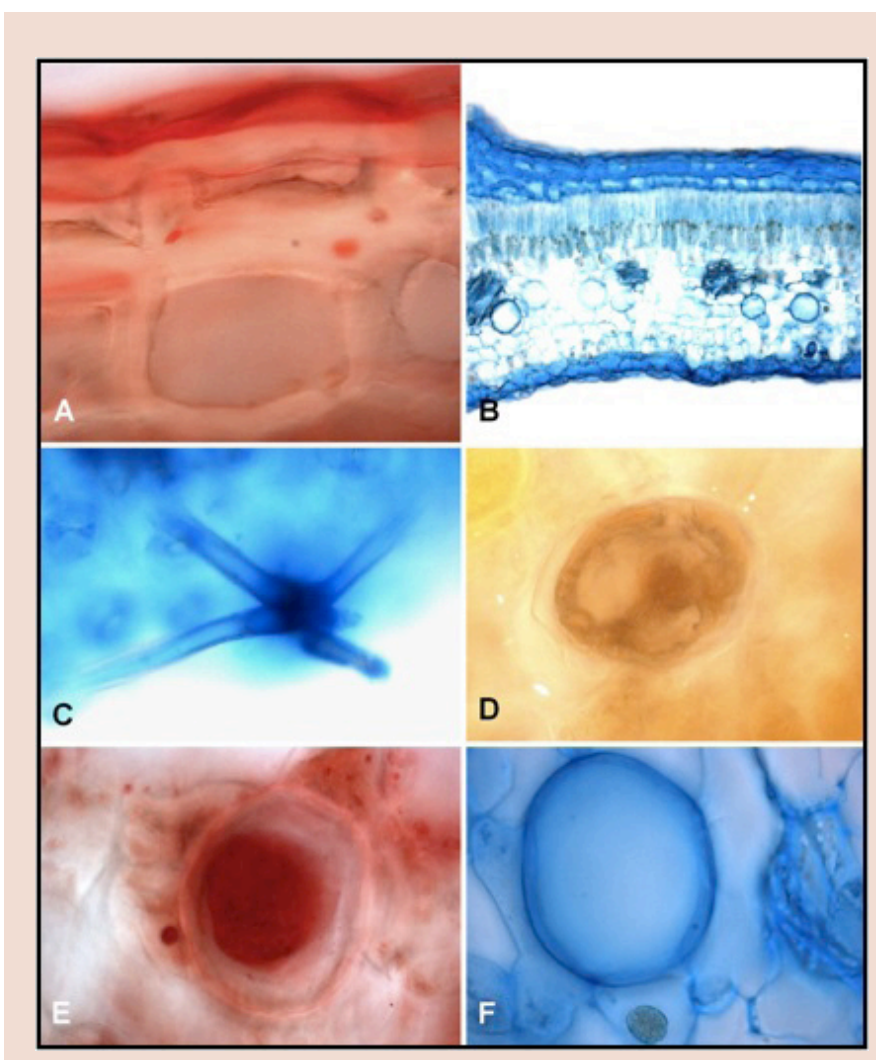

Figure 2: Photomicrographs of cross sections of the sheet. A: thick cuticle covered the leaf epidermis B: Middle region of the sheet, showing epidermal cells mis was bilayered in the adaxial side. C: stellate trichomes. D: Secretory Cel E: oil secreting cells F: crystal sand cells. 


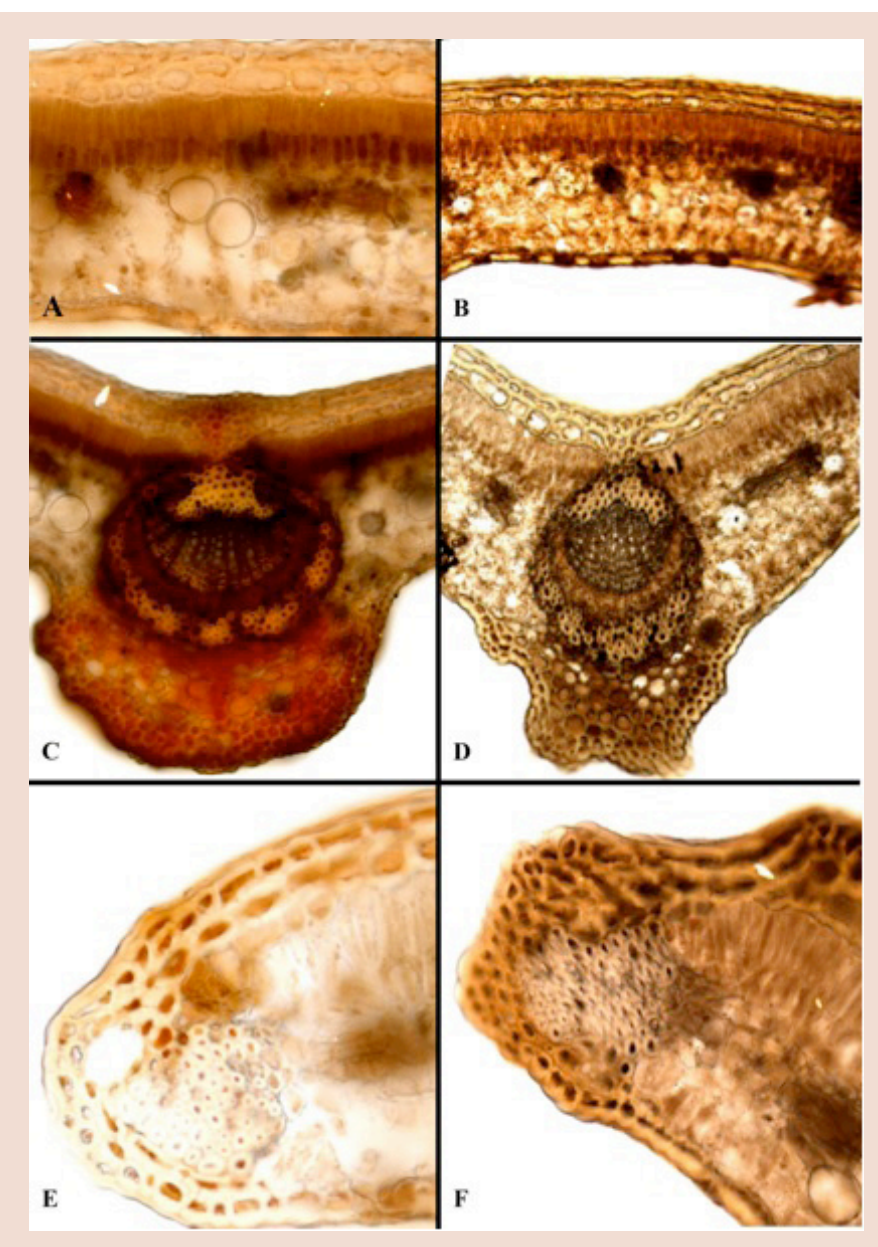

Figure 3: Anatomy of $P$ boldus. A: Content and walls of epidermic and parenchymatic cells (Wagner Reagent). B: Content and walls of epidermic and parenchymatic cells (Iron chloride). C: Central vein (Wagner Reagent). D: central vein (Iron chloride). E: Margin (Wagner Reagent). F: Margin (Iron chloride).

The central vein was prominent in the abaxial surface (Figure $3 \mathrm{c}$ and $\mathrm{d}$ ). The tissue arrangement of central vein was different of that of mesophyll: the subepidermic tissue of adaxial side was parenchymatic and of the abaxial side was collenchymatic. The vascular cylinder was arc-shaped, constituted by xylem elements toward the adaxial side and phloematic elements toward the abaxial side; both xylem and phloem were surrounded by lignified fibers. In this region, epidermic cells slightly reacted for alkaloids and phenolic compounds; the fiber lumen slightly reacted for alkaloids (Figure 3c) and strongly reacted for phenolic compounds (Figure 3d).

The margin was constituted by four layers of thick-walled epidermic cells and a bundle of lignified fibers (Figure $3 e$ and $\mathrm{f}$ ). In this region, epidermic cells and fiber lumen slightly reacted for alkaloids (Figure 3e) and strongly reacted for phenolic compounds (Figure 3f).

The surface evaluation (SEM) confirmed the occurrence of stomata and stellate trichomes on the abaxial surface (Figure 4), and showed platelet epicuticular waxes on the adaxial surface.

Diagnostic characters found in the whole leaf were checked with those found in the milled leaves. The $75 \mu \mathrm{m}$ sized milled leaf showed split trichomes and heterogeneous particles, while the $180 \mu \mathrm{m}$ and $355 \mu \mathrm{m}$ sized milled leaves showed some intact structures, as stellate trichomes, waxes and vessels. Thus, $180 \mu \mathrm{m}$ and $355 \mu \mathrm{m}$ were the appropriate sizes for identifying Peumus boldus leaf, since stellate trichomes can be

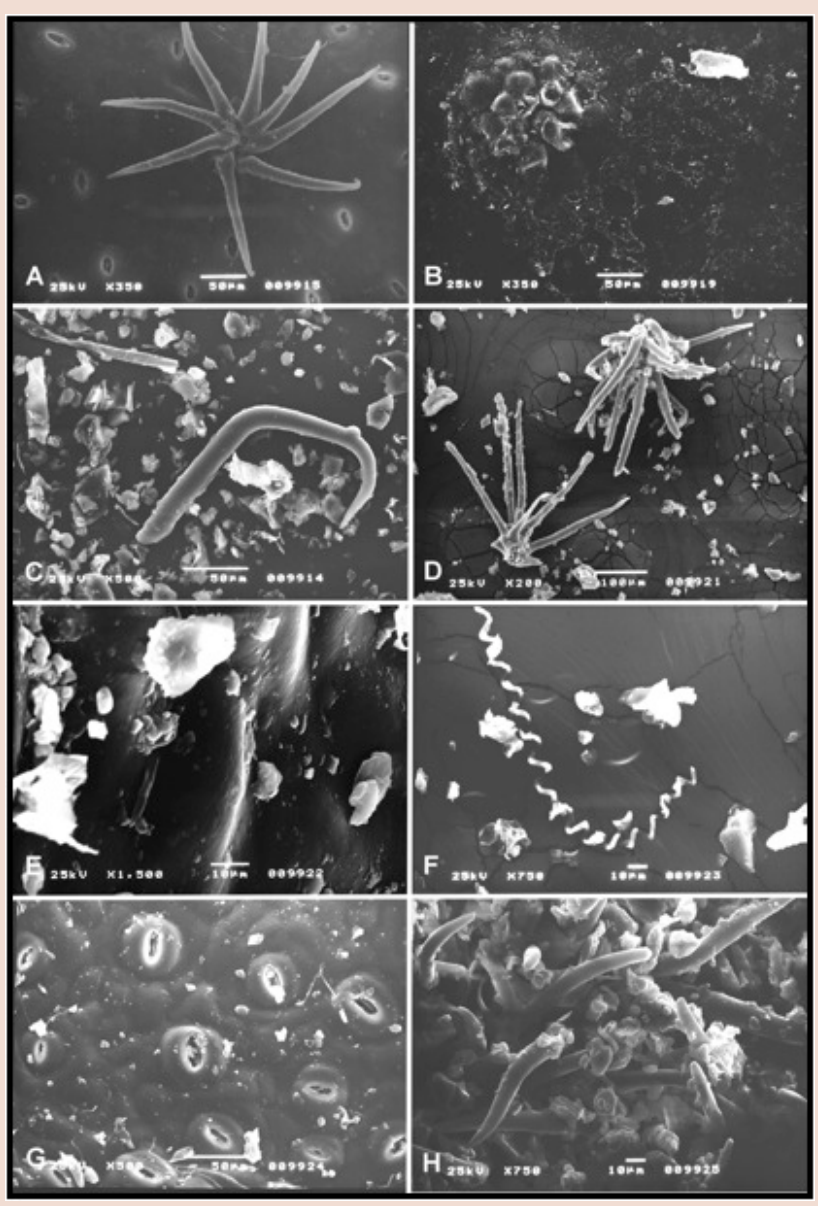

Figure 4: Surface evaluation A: Stomata and stellate trichomes on the abaxial surface. B: Platelet epicuticular waxes on the adaxial surface. C: Stellate trichomes fragments. D: Stellate trichomes fragments. E: Platelet epicuticular waxes. F: Wall with spiral thickening of a vessel element. G: Stomata. H: Stellate trichomes with waxes.

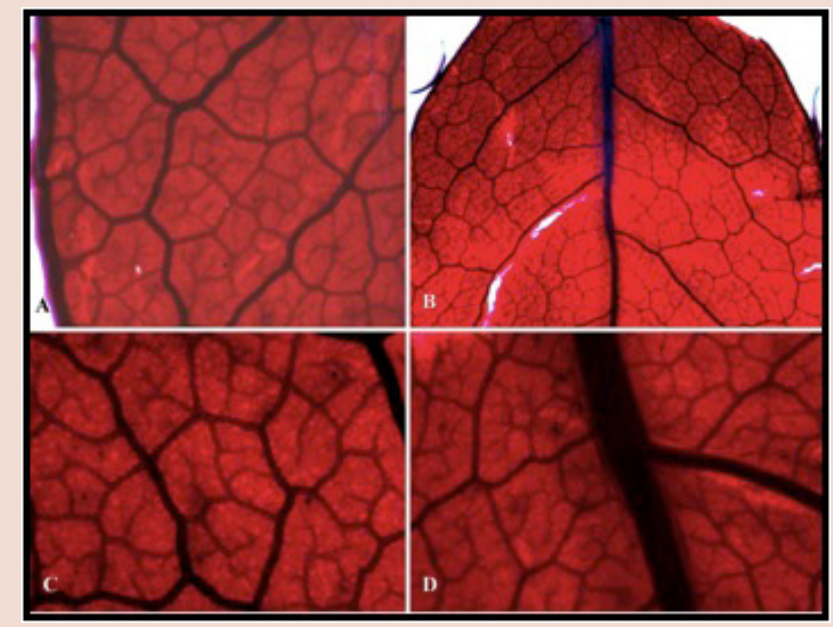

Figure 5: Diaphanized leaves. A: Marginal region; the pattern of tertiary veins-orthogonal reticulate. B: Region central; venation pattern cladodromous type, primary vein curved. Branched vascular terminations in the region between the margin and the central vein (C), (D) region of the central vein. 


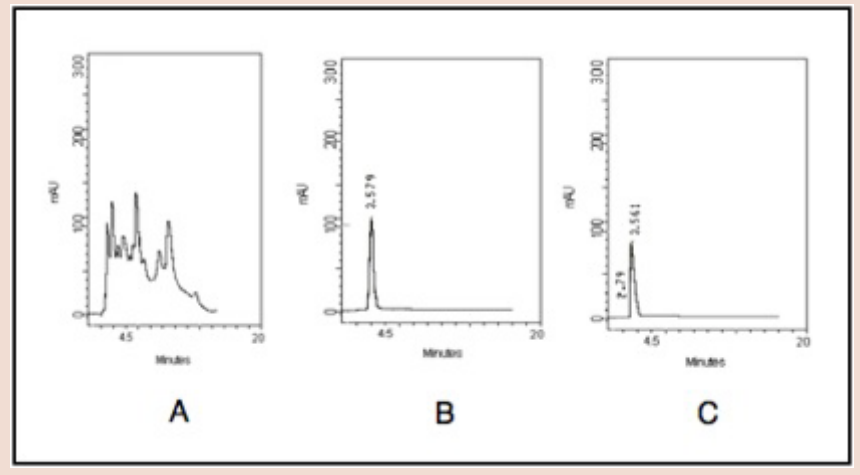

Figure 6: Chromatogram of: A: Extract crude, B: boldine standard $99.6 \%$ and C: Peumusboldus extract, after sample preparation. Mobile phase acetonitrile/ water/triethylamine 85/15/0.2 (v/v), column C18, flux 0,6 ml/mim.

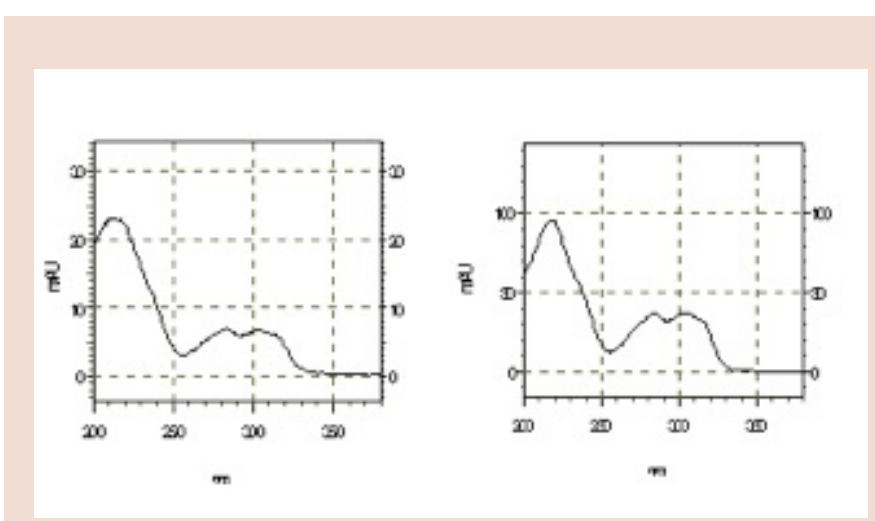

Figure 7: UV spectra of boldine standard (A), extract from leaves of Peumusboldus by maceration with clean-up method (B).

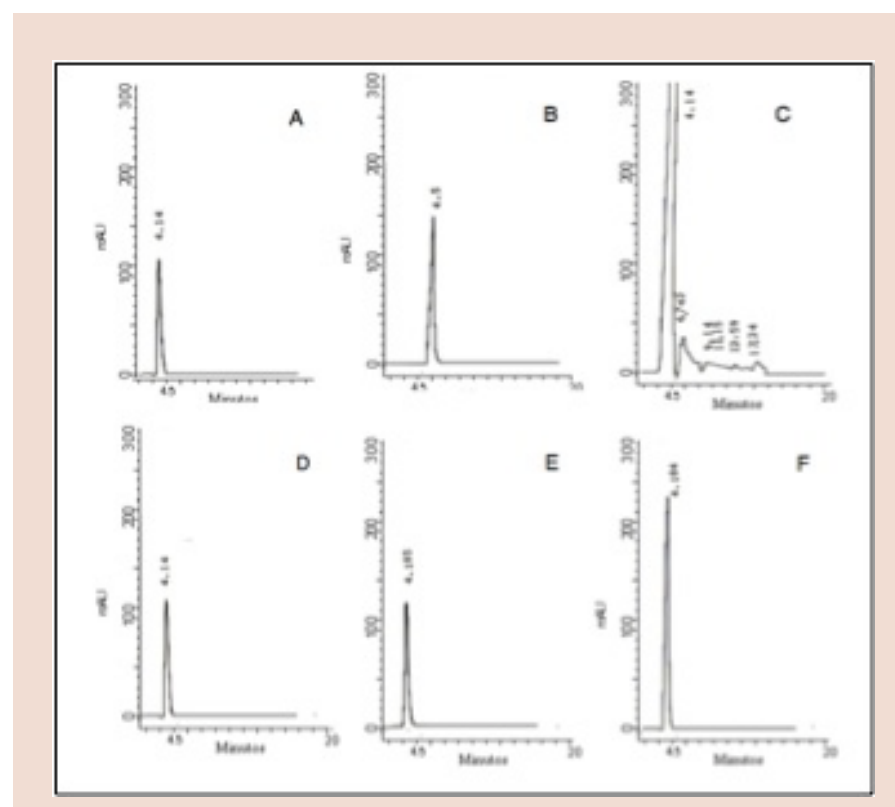

Figure 8: Chromatogram of Peumusboldus: (A) extract (B) boldine standard 99.6\% (C) extract wihboldine standard 99.6\% (D), extract-atenuation 3. Mobile phase acetonitrile/water/triethylamine 85/15/0.2 (v/v), column $\mathrm{C} 18$, flux $0,6 \mathrm{ml} / \mathrm{mim}$.

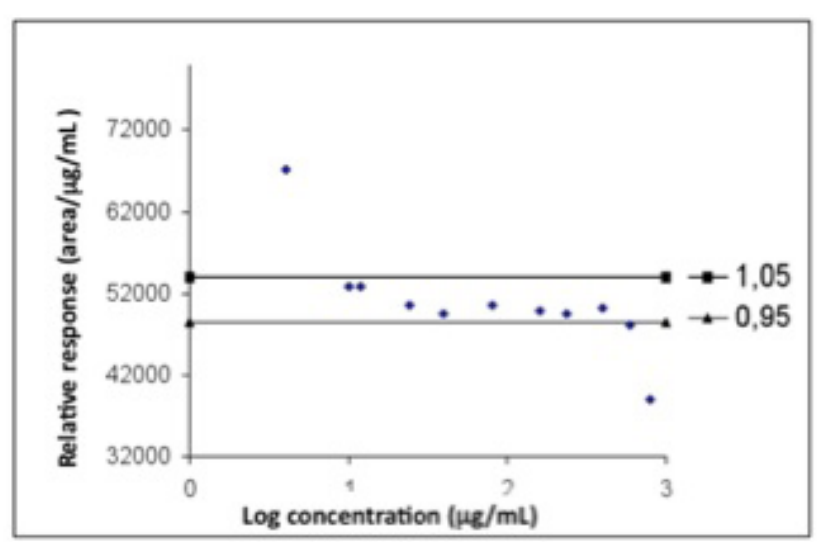

Figure 9: Charts of the responses relating versus log concentration.

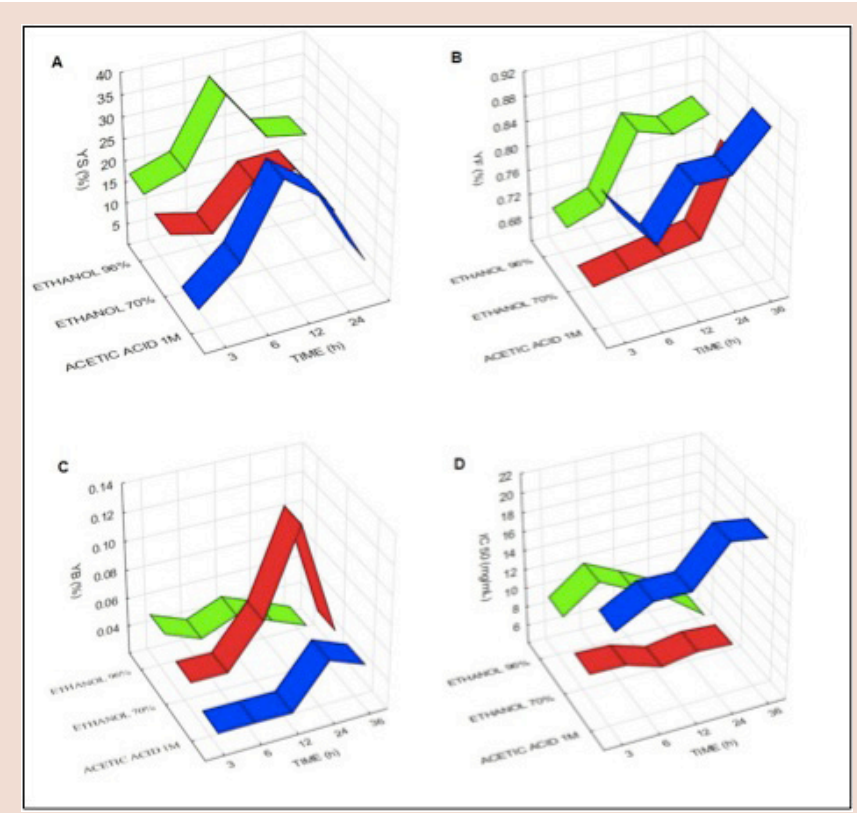

Figure 10: Soxhlet extraction: (A) Chart plot of soluble solids yield as a function time, (B) Chart plot of flavonoid yield as a function time, (C) Chart plot of boldine yield as a function time, (D) Chart plot of antioxidant activity as a function time.

considered a good diagnostic character for the drug. Stellate trichomes were not reported in other plant species popularly known as boldoPlectranthus barbatus (Lamiaceae), Plectranthus grandis (Lamiaceae) and Vernonia condensata (Asteraceae). ${ }^{45}$

According to Hickey's classification (1973), the venation pattern of Peumus boldus leaf was of cladodromous type (Figure 5b). The courses of primary and secondary vein were curved (Figure 5b); the divergence angle of secondary veins was nearly uniform and acute (Figure $5 \mathrm{~b}$ and $\mathrm{d}$ ); the intersecondary veins were composite (Figure $5 \mathrm{a}$ and c); the pattern of tertiary veins was orthogonal reticulate (Figure $5 \mathrm{a}$ and c); the quaternary and quinternary veins were thin with orthogonal course (Figure $5 \mathrm{c}$ and d); the marginal ultimate venation was looped (Figure 5a).

\section{Validation Parameters}

In order to verify the validity of the conditions of the chromatographic method, preliminary runs were made with the injection of samples of 
the crude and cleaned extracts. In the case of the cleaned extract the chromatograms showed distinct and clear peak for boldine (Figure 6).

Thus, selectivity was performed by comparing the chromatographic profiles of the analytical standards in relation to those obtained for plant biomass samples. For that purpose, the identification of the peaks was assured according to their retention times, by coelution with authentic standards and UV spectra. The chromatogram showed only one peak, with retention time and UV spectra identical to the standard, boldine (Figure 6 and 7).

In an attempt to verify the presence of other alkaloids with the same retention time of boldine, the ratios of water and acetonitrile were modified maintaining the same flow and the same column. The amount of acetonitrile was diminished until the inversion of the proportion of water, and in all analyzes it was obtained only a peak with the same retention time of the standard boldine.

To confirm the identity of the chromatographic peak, as boldine, the enrichment of the extract with the standard was done (Figure $8 \mathrm{a}, 8 \mathrm{c}$ and $8 \mathrm{~d})$.

Although there was described in Peumus boldus 17 alkaloids, boldine is the most abundant one. Considering that the extract purification used

Table 1: Histochemical analysis applied to Peumus boldus (M.) leaves

\begin{tabular}{ccc}
\hline Dy & Colour & Structure \\
\hline Wagner Reagent & Black/Brown & Alkaloids \\
Ironchloride & Black & Phenolic compounds \\
Sudam III & Red/Pink & Lipidic substances \\
Safrablau & Blue/Pink & Pectin and cellulose/lignin and \\
& & suberin \\
Fluoroglucin acidified & Pink & Lignified walls \\
\hline
\end{tabular}

Table 2: Factors and levels of the $3^{2}$ factorial design

\begin{tabular}{cccc}
\hline & \multicolumn{3}{c}{ Levels } \\
\cline { 2 - 4 } Factors & -1 & 0 & +1 \\
\hline \multirow{2}{*}{ 1) Solvent } & ACETIC ACID & ETHANOL & ETHANOL \\
& $1 \mathrm{M}$ & $70 \%$ & $96 \%$ \\
2) Time (h) & 12 & 24 & 36 \\
\hline
\end{tabular}

Table 3: Summary of results in Sohxlet extraction

\begin{tabular}{cccccc}
\hline SOLVENT & TIME (hrs) & YS (\%) & YF (\%) & YB (\%) & $I_{50}\left(\mathrm{mg} / \mathrm{mL}^{-1}\right)$ \\
\hline \multirow{2}{*}{ ETHANOL } & 3 & 18.4 & 0.70 & 0.05 & 9.3 \\
96\% & 6 & 21.4 & 0.72 & 0.04 & 12.0 \\
& 12 & 36.3 & 0.83 & 0.05 & 10.2 \\
& 24 & 24.6 & 0.81 & 0.04 & 8.3 \\
ETHANOL & 36 & 22.9 & 0.83 & 0.03 & 5.5 \\
70\% & 3 & 17.1 & 0.66 & 0.04 & 6.8 \\
& 12 & 14.8 & 0.67 & 0.04 & 6.7 \\
& 24 & 24.3 & 0.68 & 0.07 & 5.5 \\
& 36 & 12.8 & 0.81 & 0.05 & 5.9 \\
ACETIC ACID & 3 & 8.4 & 0.84 & 0.03 & 15.0 \\
1 M & 6 & 16.2 & 0.77 & 0.03 & 17.0 \\
& 12 & 32.5 & 0.85 & 0.03 & 17.0 \\
& 24 & 25.5 & 0.85 & 0.06 & 21.0 \\
& 36 & 9.45 & 0.91 & 0.05 & 20.5 \\
\hline
\end{tabular}

Table 4: Repeatability and intermediate precision

\begin{tabular}{cccc}
\hline $\begin{array}{c}\text { Repeatability } \\
\text { concentration } \\
\left(\mathrm{mgmL}^{-1}\right)\end{array}$ & $\mathrm{CV} \%$ & $\begin{array}{c}\text { Intermediate Precision } \\
\text { Concentration }\left(\mathrm{mgmL}^{-1}\right)\end{array}$ & $\mathrm{CV} \%$ \\
\hline 30.60 & 30.20 & \\
29.80 & 28.50 & \\
30.20 & 1.78 & 30.80 & 3.58 \\
30.50 & & 29.50 & \\
29.30 & & 28.00 & \\
29.50 & & 29.90 \\
\hline
\end{tabular}

Table 5: Accuracy and recovery

\begin{tabular}{|c|c|c|c|c|}
\hline $\begin{array}{c}\text { Expected } \\
\text { Concentration } \\
\left(\mu \mathrm{g} / \mathrm{mL}^{-1}\right)\end{array}$ & $\begin{array}{l}\text { Real concentration } \\
\qquad\left(\mu \mathrm{gmL}^{-1}\right)\end{array}$ & $\begin{array}{c}\text { Recovery } \\
\%\end{array}$ & $\begin{array}{c}\text { Error } \\
\%\end{array}$ & CV \% \\
\hline \multirow{5}{*}{7.5} & 6.07 & \multirow{5}{*}{80.99} & \multirow{5}{*}{-3.80} & \multirow{5}{*}{1.95} \\
\hline & 5.90 & & & \\
\hline & 6.14 & & & \\
\hline & 6.12 & & & \\
\hline & 5.90 & & & \\
\hline \multirow{5}{*}{15.0} & 12.30 & \multirow{5}{*}{82.03} & \multirow{5}{*}{-5.98} & \multirow{5}{*}{2.19} \\
\hline & 12.20 & & & \\
\hline & 12.00 & & & \\
\hline & 12.50 & & & \\
\hline & 12.70 & & & \\
\hline \multirow{5}{*}{30.0} & 24.40 & \multirow{5}{*}{81.37} & \multirow{5}{*}{-9.31} & \multirow{5}{*}{1.70} \\
\hline & 23.90 & & & \\
\hline & 24.20 & & & \\
\hline & 24.60 & & & \\
\hline & 25.00 & & & \\
\hline
\end{tabular}

Table 6: Pharmaceutical forms commercial

\begin{tabular}{cccc}
\hline $\begin{array}{c}\text { Pharmaceutical } \\
\text { forms commercial }\end{array}$ & $\begin{array}{c}\text { Real } \\
\text { concentration }\end{array}$ & Error \% & CV \% \\
\hline Capsule $(2,5 \mathrm{mg})$ & 2.3 & $92 \%$ & 1.03 \\
dragea $(0,05 \mathrm{mg})$ & 0.056 & $112 \%$ & 2.21 \\
Tablet $(1,0 \mathrm{mg})$ & 0.97 & 97 & 0.98 \\
\hline
\end{tabular}

method is for purification of alkaloids, the chromatogram should display peaks related to other alkaloids present in the extract. Changing the attenuation of cromatopac, it is possible to visualize the presence of other minor peaks, but in very low concentrations, which was not possible to quantify (Figure 8b).

The analytical curves of the standards (boldine) were prepared in concentrations ranging between 0.4 and $800 \mu \mathrm{gmL}^{-1}$. These solutions were analyzed in triplicate using the above analytical method.

The calculation of the linear range was given by the graph of the relative responses on the y axis and the corresponding concentrations in logarithmic scale on the $\mathrm{x}$ axis (Figure 9). The range of linear response varied from 10 to $400 \mu \mathrm{gmL}^{-1}$ with squared correlation coefficient of 0.9999 .

The correlation coefficients $(r)$ were determined for boldine, and linear regression obtained and its correlations were used for the deduction of equations to quantify the boldine. 
The detection and quantification limits for boldine were 1.06 and $3.2 \mu \mathrm{g} /$ $\mathrm{mL}$, respectively, rendering the method sufficiently sensitive for the present purposes.

The highest relative standard deviation found in precision tests was $3.9 \%$ and the highest coefficient of variation was $1.8 \%$ (\% bias) (Table 4 ). Therefore, the developed method presents good precision

The recoveries obtained for boldine varied from 85 to $86 \%$, with deviations lower than $3 \%$ (Table 5), which indicates that the developed method displays good accuracy.

Three different pharmaceutical commercial forms of boldo (capsule, dragee and tablet) were analyzed. In capsule it was found $2.3 \mathrm{mg}$ of boldine, in dragee, $0.056 \mathrm{mg}$ and in tablet $0.97 \mathrm{mg}$, which matched with the values indicated by the manufacturer as $2.5 \mathrm{mg}, 0.05 \mathrm{mg}$ and $1.0 \mathrm{mg}$, respectively (Table 6).

Considering the results, this HPLC method may be considered reliable, accurate and precise for boldine quantification.

Moreover, the developed method uses lower proportion of acetonitrile and lower flow than that of Pietta et al. ${ }^{33}$ reducing the cost of solvent and producing less environmental impact. Furthermore, Pietta et al. ${ }^{33}$ and De Orsi et al..$^{46}$ uses Sep-Pak cartridge for the preparation of the sample, and in this paper we used liquid-liquid extraction, which is cheaper and commonly used technique in laboratories.

\section{Soxhlet Extraction}

The Soxhlet extraction conditions were evaluated by the extract properties, such as the soluble solids, boldine, flavonoid yields and antioxidant activity. The soluble solids yielding, YS, for the three solvents and different extraction times are shown in Figure 10a. YS increased with extraction time up to $12 \mathrm{~h}$, and then decreases with significant level of $5 \%$. This effect of extraction time was observed for all three solvents used. During the experiments, after $12 \mathrm{~h}$ of experiment a thin film of extractives was deposited at the flask glass wall, caused by the co-extraction of undesirable resinous substances from boldo leafs. As the material stick to the walls was not collected, this is the most probable cause of decreasing of soluble solids content in extracts. On the other hand, the solvent type did not affect significantly $(\mathrm{P}>0.05)$ the soluble solids extraction.

However, the flavonoid yield, YF, increased steadily with extraction time up to $36 \mathrm{~h}$ for ethanol $70 \%$ (Figure 10b). The extraction with ethanol $96 \%$ and acetic acid $1 \mathrm{M}$ showed an increasing YF up to $12 \mathrm{~h}$, and then it remained constant up to $36 \mathrm{~h}$. The final YF $(36 \mathrm{~h})$ was similar for ethanol $70 \%$ and $96 \%$, and higher for acetic acid $1 \mathrm{M}$. Nevertheless, it is shown in Table 2 that the extraction with ethanol $70 \%$ is slower than with other solvents.

The extraction of boldine during Soxhlet extraction with ethanol 96\% and acetic acid $1 \mathrm{M}$ was not affected by extraction time (Figure 10c). However, YB showed a maximum yield within $24 \mathrm{~h}$ for ethanol $70 \%$ and the final yield at $36 \mathrm{~h}$ was similar to the other solvents.

The extracts concentrations to reduce $50 \%$ of the $\mathrm{DPPH}, \mathrm{IC}_{50}$, obtained by Soxhlet extraction are shown in Figure $10 \mathrm{~d}$. The $\mathrm{IC}_{50}$ seems to be independent of extraction time for ethanol $70 \%$, while it increased with time for acetic acid $1 \mathrm{M}$ and showed a maximum at $6 \mathrm{~h}$ for ethanol $96 \%$. The statistical analysis showed that solvent type affected $\mathrm{IC}_{50}$ with high significance $(0.01 \%$ level).

\section{DISCUSSION}

The World Health Assembly in resolutions has emphasized the need to ensure the quality of medicinal plant products by using current control techniques and applying appropriate standards. The quantitative determination of some pharmacognostical parameters is useful for setting standards for crude drugs. With this backdrop, it becomes extremely important to make an effort towards standardization of the plant material to be used as a medicine. Thus, in recent years, there has been an emphasis on standardization of medicinal plants of therapeutic potential. According to the World Health Organization (WHO) the macroscopic and microscopic description of a medicinal plant is the first step towards establishing its identity and purity and should be carried out before any tests are undertaken. ${ }^{47}$

The quality control methods are important tool in traditional medicines which serve as useful information for identification, authentication and standardization of herbal medicine. The safety and efficacy of herbal medicines are dependent on the standardization and quality of plant materials. ${ }^{48}$ Macroscopic and microscopic methods can help to identify and authenticate plant materials. The macroscopic and microscopic analysis of dried leaves showed that these samples were authentic, i.e., correspond to the leaf description of Peumus boldus found in the literature. Morphological identification, even if it was not the only method employed, has an important role on quality control, especially due to its low cost, allowing to check on raw material almost immediately, verifying their identity and thus preventing fraud or adulteration.

Extracts of Peumus boldus have been used in folk medicine for the treatment of liver ailments. The therapeutic properties of crude extracts of Peumus boldus have been suggested to be associated with the presence of polyphenolic compounds, mainly to the alkaloid boldine. ${ }^{4,49}$ Accordingly, literature has indicated that flavonoid, boldine and crude extracts from Peumus boldus contribute to the protection against free radicals. Free radicals promote oxidative damage, which plays a rolein the pathogenesis of many diseases, including cancer, arthritis, atherosclerosis, Alzheimer's disease and diabetes. ${ }^{49-51}$

Antioxidants and their chemical properties are currently a subject of intensive research. This is stimulated by the fact that oxidative stress in vivo may cause various problems, associated with numerous degenerative aging diseases, such as cancer and arteriosclerosis. Oxidative stress caused by reactive oxygen species (ROS) is a specific feature in the pathogenesis of various diseases, including cancer, cardiovascular diseases, diabetes, tumors, rheumatoid arthritis and epilepsy. In recent years, considerable attention has been paid to antioxidant properties of plants that may be used for human consumption. ${ }^{52,53}$

Furthermore, although the evidences of flavonoids and boldine biological effects are remarkable in the literature, ${ }^{3,6}$ making them key chemical markers for boldo products, it would be temerarious to affirm that one of them is more important than others for boldo clinical activity. On the other hand, there is plenty of evidence of biological activities of both flavonoids and alkaloids in the literature ${ }^{6}$ and there is strong evidence of synergistic effect among these constituents of plant extracts. Recently, one of the most accepted alternatives to evaluate plant extracts biological activity is the antioxidant property. The DPPH is an important method for antioxidant activity determination and it should be preferred as a quality indicator in the work herein. ${ }^{54}$

Besides, the Soxhlet results showed diverse effects of the solvents and process time on the extract flavonoid and boldine contents and $\mathrm{IC}_{50}$. The Soxhlet is a traditional method for extraction of natural substances for further quantification, and is considered effective because it is an exhaustive technique. However, the results herein prove that Soxhlet conditions should also be investigated to achieve the maximum extraction yielding. Despite the influence of the azeotropic mixture ethanol/water $(95: 5 \mathrm{v} / \mathrm{v})$ there was a difference in the extraction using ethanol $70 \%$ and $96 \%$, showing that under the conditions studied the water content in the solvent influenced the extraction of Peumus boldus. This may be due to fewer theoretical plates for increasing water content or the faster filling of drug cartridge when using $96 \%$ ethanol. Bimakr et al. ${ }^{55}$ studied the 
Soxhlet extraction of spearmint (Menthaspicata L.) using ethanol 70\% to $96 \%$ and obtained higher yields of flavonoids using ethanol $70 \%$.

The results showed that the conditions of extraction were also important for the Soxhlet. The soluble solids yields ranged from 9.5 to $36.3 \%$ for the Soxhlet. Those yields of bold leafs are higher than the previously reported by Quezada et al., ${ }^{6}$ Valle et al. ${ }^{56}$ which obtained 14 and 13\% respectively, using ethanol as solvent. Gotteland et al., ${ }^{15}$ using ethanol $96 \%$, reported a yield value $(25 \%)$ closer to this work. However, these authors did not study the process effect factors on soluble solids yielding. This may also be an explanation to the different yields reported by those authors.

The flavonoid contents (TF) varied from 2.30 to $3.01 \%$ for Soxhlet. The TF in this work were higher than that reported by Krug and Borkowsky, ${ }^{57}$ by Schmeda-Hirschmann et al. ${ }^{58}$ and by Quezada et al. ${ }^{6} 0.065,2.45$ and $1.41 \%$, respectively. The flavonoid yields (YF) ranged from 0.68 to $0.90 \%$ for the Soxhlet.

The same was observed for boldine yieldings. The boldine yield (YB) varied from 0.03 to $0.13 \%$ for Soxhlet. Previous authors have found similar data, Hulle et al. ${ }^{2} 0.03 \%$, Gotteland et al. ${ }^{15} 0.12 \%$, Vogel et al. ${ }^{59} 0.087 \%$, Quezada et al. ${ }^{6} 0.14 \%$ and Valle et al. ${ }^{56} 0.0056 \%$.

The antioxidant activity, expressed as $\mathrm{IC}_{50}$ ranged from 5.5 to $21.0 \mu \mathrm{g} / \mathrm{mL}$ for Soxhlet extracts. The highest antioxidant activities were obtained with ethanol $70 \%$. These correspond to $\mathrm{IC}_{50}$ of 5.5 and $6.3 \mu \mathrm{g} / \mathrm{mL}$, respectively, and can be considered high antioxidant activities. For illustrative purpose, using the same method (DPPH) comparable values of $\mathrm{IC}_{50}$ has been reported for pure vitamin $\mathrm{C}, 4.2 \mu \mathrm{g} / \mathrm{mL}$.

Besides, the quantification method developed here proved to be reliable for the quantification of boldine in fluid extract and in different pharmaceutics forms, and it can be used for routine quality control of boldo materials. Furthermore, this study revealed that the most significant factor for flavonoid, boldine, and antioxidant activities extraction is the used solvent. Also, the best conditions for extraction of flavonoids do not coincide with the conditions for highest boldine yieldings and antioxidant activities. However, based on the highest boldine content and antioxidant activity, ethanol $70 \%$ was the best solvent.

\section{CONCLUSION}

The methods proposed in this paper can be used for the quality assurance of boldo dried leaves, standardized extracts, dried extracts, tablets and capsules.

\section{ACKNOWLEDGEMENT}

The financial support from CNPq and Fapesp process No.2013/23327-5 are gratefully acknowledged. We thank Maria Dolores Seabra Ferreira and José Augusto Maulin (TEM Laboratory/BCMBP, FMRP-USP) for technical assistance.

\section{CONFLICT OF INTEREST}

The authors declare that they have no conflict of interests.

\section{ABBREVIATION USED}

HPLC: High-Performance Liquid-Chromatography; LC: NMR: liquid chromatography with parallel NMR; UV: Ultraviolet; UV: Vis-ultraviolet-visible; LM: microscopic observations under light; SEM: scanning electron microscopy; FDA: Food and Drug Administration; LOD: limits of detection; LOQ: Limit of quantitation; RSD: Relative standard deviation; CV: Coefficient variation; YS: Solid Yield; YB: Boldine Yield; YF: Flavonoid Yield; TF: Flavonoid Contents; IC $_{50}$ : Extract concentration $\left(\mathrm{mgmL}^{-1}\right)$ required to inhibit 50\%; WHO: World Health Organization; ROS: Reactive oxygen species; DPPH: 2,2-diphenylpicrylhydrazil.

\section{REFERENCES}

1. Taylor L. Herbal Secrets of Rainforest. Austin; 2002

2. Vanhulle $C$, Braeckman $P$ Vanseveren R. Influence of the Preparation Technique on the Boldine Content of Boldo Dry Extract. J Pharm Belg. 1983;38(2):97-100.

3. Speisky H, Cassels BK. Boldo and Boldine-an Emerging Case of Natural Drug Development. Pharmacol Res. 1994;29(1):1-12.

4. Speisky H, Cassels BK, Lissi EA, Videla LA. Antioxidant Properties of the Alkaloid Boldine in Systems Undergoing Lipid-Peroxidation and Enzyme Inactivation. Biochem Pharmacol. 1991;41(11):1575-81.

5. Speisky H, Squella JA, Nunezvergara LJ. Activity of Boldine on Rat lleum. Planta Med. 1991;57(6):519-22.

6. Quezada N, Asencio M, del Valle JM, Aguilera JM, Gomez B. Antioxidant activity of crude extract, alkaloid fraction, and flavonoid fraction from boldo (Peumus boldus Molina) leaves. J Food Sci. 2004;69(5):C371-C6.

7. O'brien P, Carrasco-Pozo C, Speisky H. Boldine and its antioxidant or healthpromoting properties. Chem-Biol Interact. 2006;159(1):1-17.

8. Simirgiotis MJ, Schmeda-Hirschmann G. Direct identification of phenolic constituents in Boldo Folium (Peumus boldus Mol.) infusions by high-performance liquid chromatography with diode array detection and electrospray ionization tandem mass spectrometry. J Chromatogr A. 2010;1217(4):443-9.

9. Vogel H, Gonzalez B, Razmilic I. Boldo (Peumus boldus) cultivated under different light conditions, soil humidity and plantation density. Ind Crop Prod. 2011; 34(2):1310-2.

10. Echeverria J, Niemeyer HM. Alkaloids from the native flora of Chile: a review. B Latinoam Caribe PI. 2012;11(4):291-305.

11. Lau YS, Machha A, Achike FI, Murugan D, Mustafa MR. The aporphine alkaloid boldine improves endothelial function in spontaneously hypertensive rats. Exp Biol Med. 2012;237(1):93-8.

12. Soto C, Caballero E, Perez E, Zuniga ME. Effect of extraction conditions on total phenolic content and antioxidant capacity of pretreated wild Peumus boldus leaves from Chile. Food Bioprod Process. 2014;92(C3):328-33.

13. Lanhers MC, Joyeux M, Soulimani R, Fleurentin J, Sayag M, Mortier F. Hepatoprotective and Antiinflammatory Effects of a Traditional Medicinal Plant of Chile, Peumus-Boldus. Planta Med. 1991;57(2):110-5.

14. Backhouse N, Delporte C, Givernau M, Cassels BK, Valenzuela A Speisky H. Antiinflammatory and Antipyretic Effects of Boldine. Agents Actions. 1994;42(3-4):114-7.

15. Gotteland M, Espinoza J, Cassels B, Speisky H. Effect of a Dry Boldo Extract on Oro Cecal Intestinal Transit-Time in Healthy-Volunteers. Rev Med Chile. 1995;123(8):955-60

16. Vila R, Valenzuela L, Bello H, Canigueral S, Montes M, Adzet T. Composition and antimicrobial activity of the essential oil of Peumus boldus leaves. Planta Med. 1999;65(2):178-9.

17. Jang YY, Song JH, Shin YK, Han ES, Lee CS. Protective effect of boldine on oxidative mitochondrial damage in streptozotocin-induced diabetic rats. Pharmacol Res. 2000;42(4):361-71.

18. Santanam N, Penumetcha M, Speisky H, Parthasarathya S. A novel alkaloid antioxidant, Boldine and synthetic antioxidant, reduced form of RU486, inhibit the oxidation of LDL in vitro and atherosclerosis in vivo in LDLR-/(-) mice. Atherosclerosis. 2004;173(2):203-10.

19. Pastene E, Parada V, Avello M, Ruiz A, Garcia A. Catechin-based Procyanidins from Peumus boldus Mol. Aqueous Extract Inhibit Helicobacter pyIori Urease and Adherence to Adenocarcinoma Gastric Cells. Phytother Res. 2014;28(11):1637-45.

20. Diaz-Reinoso B, Moure A, Dominguez $H$, Parajo JC. Supercritical $\mathrm{CO}_{2}$ extraction and purification of compounds with antioxidant activity. Journal of Agricultural and Food Chemistry. 2006;54(7):2441-69.

21. Song W, Derito CM, Liu MK, He XJ, Dong M, Liu RH. Cellular Antioxidant Activity of Common Vegetables. Journal of Agricultural and Food Chemistry. 2010;58(11):6621-9.

22. Khuniada C, Thitikornpongb W, Palanuveja C, Ruangrungsia N. Pharmacognostic evaluation and chrysazin quantitation of Xyris indica flowering heads. Pharmacognosy Journal. 2014;6(4):16-22.

23. Casagrande R, Baracat MM, Georgetti S, Verri Jr WA, Vicentini F, Rafael JA Method validation and stability study of quercetin in topical emulsions. Quim Nova. 2009;32(7):1939-42

24. Malcangio AM. [Colorimetric determination of boldine]. II Farmaco Edizione Scientifica. 1955;10(5):262-7.

25. Di Renzo N. [Densitometric determination of boldine in boldo extracts]. Bollettino Chimico Farmaceutico. 1972;111(7):450-3

26. Gurkan T. Fluorimetric Analysis of Alkaloids-Determination of Serpentine, Yohimbine, and Boldine. Mikrochim Acta. 1976;1(2-3):173-80.

27. Vilchez JL, Sanchezpalencia G, Avidad R, Navalon A. Determination of Boldine in Drug Formulations by 1st-Derivative Synchronous Spectrofluorometry. J Pharmaceut Biomed. 1994;12(3):313-7.

28. Sun SW, Lee SS, Chen LY, Chen CK. Separation of aporphine alkaloids by micellar electrokinetic chromatography. J Chromatogr A. 1997;767(1-2):277-84 
29. Sun SW, Chen LY. Optimization of micellar electrokinetic chromatographic separation of aporphine alkaloids by overlapping resolution mapping. J Liq Chromatogr R T. 1998;21(11):1613-27.

30. Nunez-Vergara LJ, Squella JA, Berrios-Sagredo EA. Voltammetric study of boldine on stationary platinum electrode. II Farmaco Edizione Pratica. 1983;38(5):219-26

31. Camara Cl, Bornancini CA, Cabrera JL, Ortega MG Yudi LM. Quantitative analysis of boldine alkaloid in natural extracts by cyclic voltammetry at a liquid-liquid interface and validation of the method by comparison with high performance liquid chromatography. Talanta. 2010;83(2):623-30.

32. Hroch M, Micuda S, Cermanova J, Chladek J Tomsik P. Development of an HPLC fluorescence method for determination of boldine in plasma, bile and urine of rats and identification of its major metabolites by LC-MS/MS. J Chromatogr B. 2013;936(1):48-56.

33. Pietta P, Mauri P, Manera E Ceva P. Determination of Isoquinoline Alkaloids from Peumus-Boldus by High-Performance Liquid-Chromatography. J Chromatogr. 1988;457(1):442-5

34. USPXXIII. United States Pharmacopeia. Twinbrook Parkway, Rockville; 1995.

35. Oliveira F, Akisue G Akisue MK. Farmacognosia. São Paulo, Atheneu; 1996.

36. Palma S, Lujan C, Llabot JM, Barboza G, Manzo RH, Allemandi DA. Design of Peumus boldus tablets by direct compression using a novel dry plant extract. Int J Pharm. 2002;233(1-2):191-8.

37. Marquele FD, Stracieri KM, Fonseca MJV, Freitas LAP. Spray-dried propolis extract. I: Physicochemical and antioxidant properties. Pharmazie. 2006;61(4): 325-30

38. Brasil A (2010). Resolution No 899: Guide for validation of analytical and bioanalytical methods. Sanitária ANdV.

39. USA FDA (2001). Guidance for Industry: Bioanalytical Method Validation. Services DoHaH. US, Food and Drug Administration,.

40. Ribani M, Grespan CB, Bottoli CBG, Collins CH, Jardim ICSF C.; MLF. Validação em métodos cromatográficos e eletroforéticos Quim. Nova. 2004;27(5):771-80.

41. Tiossi RFJ, Costa JC, Miranda MA, Praça FSG, Bentley MVLB, Bastos JK. A validated hplc analytical method for the analysis of solasonine and solamargine in in vitro skin penetration studies. Quim Nova. 2004;27(5):771-80.

42. Tiossi RFJ, Miranda MA, Sousa JPB, Praça FSG, Bentley MVLB, McChesney JD, Bastos JK. A Validated Reverse Phase HPLC AnalyticalMethod for Quantitation of Glycoalkaloids in Solanum lycocarpum and Its Extracts. Journal of Analytical Methods in Chemistry. 2012;2012(1):1-8.

43. Furr M, Mahlberg PG. Histochemical Analyses of Laticifers and Glandular Trichomes in Cannabis-Sativa. J Nat Prod. 1981;44(2):153-9.

44. Olatubosun MASOV. Pharmacognostic and free radical scavenging Evaluation of Cyathula prostata (Blume) L. Pharmacognosy Jounal. 2015;7(2):107-116.

45. Costa MC, Teixeira-Castro $A$, Constante $M$, Magalhaes $M$, Magalhaes $P$, Cerqueira $\mathrm{J}$ Exclusion of mutations in the PRNP, JPH3, TBP, ATN1, CREBBP, POU3F2 and FTL genes as a cause of disease in Portuguese patients with a Huntington-like phenotype. Journal of Human Genetics. 2006;51(8):645-51.

46. DeOrsi D, Gagliardi L, Manna F Tonelli D. HPLC analysis of boldine in pharmaceuticals. Chromatographia. 1997;44(11-12):619-22.

47. Sonibare MA, Olatubosun OV. Pharmacognostic and free radical scaveng ing Evaluation of Cyathula prostata (Blume) L. Pharmacognosy Journal. 2015;7(2):107-16.

48. Magiera S, Baranowska I, Lautenszleger A. UHPLC-UV method for the determination of flavonoids in dietary supplements and for evaluation of their antioxidant activities. J Pharm Biomed Anal. 2015;102(1):468-75.

49. Fale PL, Amaral F, Madeira PJA, Silva M, Florencio MH, Frazao FN. Acetylcholinesterase inhibition, antioxidant activity and toxicity of Peumus boldus water extracts on HeLa and Caco-2 cell lines. Food Chem Toxicol. 2012;50(8):2656-62

50. Klimaczewski CV, Saraiva RD, Roos DH, Boligon A, Athayde ML, Kamdem JP. Antioxidant activity of Peumus boldus extract and alkaloid boldine against damage induced by Fe(II)-citrate in rat liver mitochondria in vitro. Ind Crop Prod. 2014;54(1):240-7.

51. Sait $S$, Hamri-Zeghichi $S$, Boulekbache-Makhlouf $L$, Madani $K$, Rigou $P$ Brighenti V. HPLC-UV/DAD and ESI-MS(n) analysis of flavonoids and antioxidant activity of an Algerian medicinal plant: Paronychia argentea Lam. J Pharm Biomed Anal. 2015:111(1):231-40.

52. Kalia K, Sharma K, Singh HP, Singh B. Effects of Extraction Methods on Phenolic Contents and Antioxidant Activity in Aerial Parts of Potentilla atrosanguinea Lodd. and Quantification of Its Phenolic Constituents by RP-HPLC. Journal of Agricultural and Food Chemistry. 2008;56(21):10129-34.

53. Kajdzanoska M. Petreska J, Stefova M. Comparison of Different Extraction Solvent Mixtures for Characterization of Phenolic Compounds in Strawberries. Journal of Agricultural and Food Chemistry. 2011;59(10):5272-8.

54. Beretta G, Artali R, Facino RM, Gelmini F. An analytical and theoretical approach for the profiling of the antioxidant activity of essential oils: the case of Rosmarinus officinalis L. J Pharm Biomed Anal. 2011;55(5):1255-64.

55. Bimakra M, Rahmana RA, Taipa FS, Ganjloob A, Salleha LM, Selamatc J. Comparison of different extraction methods for the extraction of major bioactive flavonoid compounds from spearmint (Mentha spicata L.) leaves. Food Bioprod Process. 2011:89(1):67-72

56. del Valle JM, Rogalinski T, Zetzl C, Brunner G. Extraction of boldo (Peumus boldus M.) leaves with supercritical $\mathrm{CO}(2)$ and hot pressurized water. Food Res Int. 2005;38(2):203-13.

57. Krug H, Borkowski N. Neue Flavonoid-Glykoside aus den Blattern von Peumus boldus. Die Pharmaceutical. 1965;20(11):692-8.

58. Schmeda-Hirschmann G, Rodriguez JA, Theoduloz C, Astudillo SL, Feresin GE Tapia A. Free-radical scavengers and antioxidants from Peumus boldus $\mathrm{Mol}$. ("Boldo"). Free Radical Res. 2003;37(4):447-52.

59. Vogel H, Razmilic I, Munoz M, Doll U, Martin JS. Studies of genetic variation of essential oil and alkaloid content in boldo (Peumus boldus). Planta Med. 1999;65(1):90-1.

\section{PICTORIAL ABSTRACT}
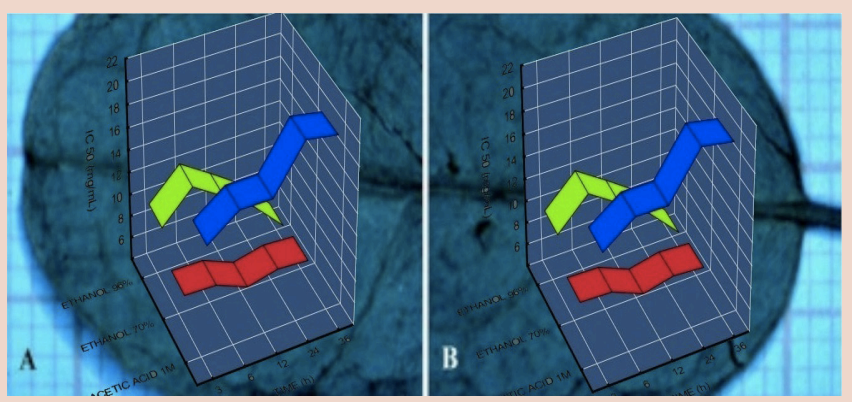

\section{SUMMARY}

- The Plant material was submitted to a pharmacognostic evaluation through morpho-anatomical diagnosis, showing that starlike trichomes can be used for boldo authentication.

- The HPLC validated analytical method is reliable, accurate and precise for boldine quantification. The Soxhlet extraction conditions were optimized.

- The methods proposed in this paper can be used for the quality assurance of boldo dried leaves, standardized extracts, dried extracts, tablets and capsules.

\section{ABOUT AUTHORS}

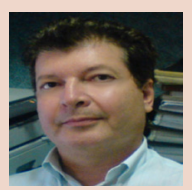

Luis Alexandre Pedro de Freitas: BSc in Chemical Enginering from Universidade Estadual de Campinas (1987), MSc and PhD in Chemical Engineering from Universidade Federal de São Carlos (1991, 1996). Visiting Scientist at University of British Columbia-Canada (1997-1999). Professor at the Faculdade de Ciências Farmacêuticas de Ribeirão Preto since 1989. Has solid experience in Industrial Pharmacy, focusing on Pharmaceutical Technology, acting on the following subjects: fluidized beds, spray drying, spray congealing, drying, granulation and coating, solid dispersions and factorial designs.

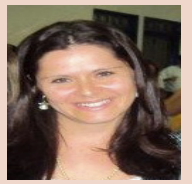

Cristiane Cardoso Correia Teixeira: BSc in Pharmacy from UNESP (2003), MSc and PhD in Pharmacy from University de São Paulo $(2006$, 2010). Lecturer in Biotechnology at UNIFEB and UNAERP. Post doctorate at FCFRP/USP, Brazil. 